\title{
Influence of Adding Fermented Whey Cheese into Drinking Water of Laying Hens
}

\author{
Mustofa Hilmi*, Anis Usfah Prastujati, Asmaul Khusnah, Muhammad Habib Khirzin and Deni Yannuarista \\ Study Program of Livestock Product Processing Technology, Politeknik Negeri Banyuwangi, Banyuwangi, East Java, Indonesia \\ *Corresponding author's E-mail: mustofahilmi@poliwangi.ac.id; ORCID: 0000-0002-4045-2576
}

Received: 28 Dec. 2019

Accepted: 06 Feb. 2020

\begin{abstract}
Cheese production waste contains carbon source, one of which is lactose as an energy source in the development of fermentation, especially in the manufacture of probiotics for poultry. The research method used $3 \%$ fermented cheese whey in 17-week-old laying hen drinking water to analyze the productivity of laying hens and microbiology. The purpose of the research is to determine the effective concentration of fermented whey cheese to improve productivity, physical and chemical composition of eggs, and evaluate fat metabolism in laying hens. The present study used 120 laying hens aged 17 weeks. The experimental method was designed using the T-test method of control (P0), fermented whey cheese (P1). The observed variables were productivity (feed consumption, water consumption, daily egg production, feed conversion ration), and microbiology of small intestine and excreta (lactate acid bacteria, salmonella, Escherichia coli.). The effect of adding fermented whey cheese into drinking water decreased feed consumption and FCR in contrast to the control group (P0) but increased egg production, egg weight, and egg mass weight. The effect of adding fermented whey cheese into drinking water decreased the number of Escherichia coli bacteria and increases lactic acid bacteria in the digestive tract of broiler chickens, especially in the ileum, caeca, so also with those in the stool. The number of Salmonella Bacteria was significantly decreased and very significantly increased lactic acid bacteria in the feces during the fermentation of whey cheese. The decrease in ammonia in the stool was very significant compared to the control group. In conclusion, adding fermented whey cheese into drinking water can reduce feed consumption, feed conversion ratio (FCR), Escherichia coli, salmonella, ammonia $\left(\mathrm{NH}_{3}\right)$, and increase egg production, egg weight, egg mass weight, final body weight, and lactate acid bacteria. The use of fermented whey cheese can be used as a nutraceutical feed additive to inhibit pathogenic bacteria in the intestine and increase lactic acid bacteria.
\end{abstract}

Key words: Drinking water, Fermented, Laying hens, Whey cheese

\section{INTRODUCTION}

Whey is a liquid cheese waste or a milk serum which is produced during the cheese production and separated from a large number of curd which mainly are not utilized by the Community, and therefore resulting in environmental pollution if directly disposed without processing (Prasetyo and Kustiawan, 2012). According to Nursiwi et al. (2015) the waste of cheese production contains carbon sources such as lactose as a source of energy in the development of biotechnology fermentation, mainly producing the probiotics for livestock. Lactose content (4-7\%) and proteins (0.6-1\%), which could be used as a medium for bacterial growth in the fermentation process was very beneficial for livestock health and increase the productivity of organic livestock (Prasetyo and Kustiawan, 2012). Also it could be used as an increased biomass medium to develop lactic acid bacteria and yeasts and produce several bioactive components through Biofermentation (Ariyanti and Hadiyanto, 2013; Nursiwi et al., 2015; Watson et al., 2017). According to Watson et al. (2017) fermentation products had a role in assisting the absorption process of vitamin $\mathrm{D}$ and $\mathrm{K}$, stimulating the growth of beneficial bacteria in the small intestine and assists the process of absorption of various microsubstances such as minerals such as calcium and iron ions. This chemical and nutritional content could be applied as a nutraceutical feed additive to livestock (Mellor, 2000; Charalampopoulos and Rastall, 2009; Kabir, 2009; Sugiharto, 2016; Watson et al., 2017). Nutraceutical feed Additive was a form of feed (or part of a food) that provided medical or health benefits, including prevention and treatment of diseases, as well as enhancing the performance and production of livestock (Bhattacharyya and Roy, 2015). In other words, nutraceuticals were organic chemicals or natural feedstuffs 
that could improve health by providing physiological benefits by providing essential nutrients. Enzymes, prebiotics, probiotics, phytogenic additives, organic acids, and others were included in the nutraceutical. The role of probiotics for poultry had a positive impact on improving performance, productivity, and livestock health. According to Kabir (2009) and Kabir et al., (2005) who had expressed the administration of nutraceutical feed additive in the form of probiotics in broiler cattle could improve the performance, quality of carcasses, the number of lactic acid bacteria in the intestine, immune response and lowering stress levels. The addition of nutraceutical feed additive in the form of probiotics, prebiotics, symbiotic, and organic acids could also increase the production of eggs, egg mass and quality (Youssef et al. 2013).

\section{MATERIALS AND METHODS}

\section{Ethical approval}

The approval of this research was sorted by Politeknik Negeri Banyuwangi's ethics committee in Indonesiaand guidelines for care, and human handling of animals was strictly followed throughout the study (FASS, 2010).

\section{Animal and treatment groups}

This research used 120 laying hens (Lohman strain, Japfa comfeed, Indonesia), aged 17-weeks old and used two kinds of treatments including P0 (without fermented whey cheese, P1 (fermented whey cheese) with 10 replications. Each replication used six chickens (1 hen/cage, the dimensions for each cage were $35 \times 36 \times 42$ $\mathrm{cm})$. Drinking water was provided ad libitum and feeding was given twice a day, in the morning $(07.00 \mathrm{am})$ and afternoon $(05.00 \mathrm{pm})$. The research period was nine weeks. The research feed using the nutrients requirement recommendation of Leeson and Summers (2005). The diet contained $20 \%$ crude protein and $2900 \mathrm{kcal} / \mathrm{kg}$. The composition and nutrients content of the control diet are showed in table 1

\section{Fermentation of whey cheese}

Fermentation of whey cheese included whey cheese which was heated to $80^{\circ} \mathrm{C}$ for 10 minutes, and then mixed with $10 \%$ of molasses. The temperature dropped rapidly to $35-40^{\circ} \mathrm{C}$ with an immersion beaker glass containing a mixture of water and molasses in cold water. The next step was adding an inoculation starter to $5 \%$ kefir grain. After completing the inoculation process, the anaerobic fermentation of kefir was carried out for 24 hours at temperatures between 35 and $40^{\circ} \mathrm{C}$. At the end of the incubation period, the quality of the fermented whey cheese was analyzed (Table 2).

Table 1. Composition and nutrients contents of basal diet fed in the experimental diet of laying hens

\begin{tabular}{|c|c|}
\hline Ingredients & $(\%)$ \\
\hline Maize & 52.00 \\
\hline Soybean meal & 24.40 \\
\hline Fish meal & 8.60 \\
\hline $\begin{array}{l}\text { Rice bran } \\
\text { Corn Gluten Meal (CGM) }\end{array}$ & $\begin{array}{l}1.10 \\
2.50\end{array}$ \\
\hline Palm oil & 2.65 \\
\hline Di-Calcium Phosphate (DCP) & 1.00 \\
\hline Calcium carbonate $\left(\mathrm{CaCO}_{3}\right)$ & 6.70 \\
\hline $\begin{array}{l}\mathrm{NaCl} \\
\text { Premix }^{1}\end{array}$ & $\begin{array}{l}0.39 \\
0.50\end{array}$ \\
\hline DL-Methionine & 0.16 \\
\hline Total & 100 \\
\hline \multicolumn{2}{|l|}{ Nutrient content $^{2}$} \\
\hline Metabolism Energy (kcal/kg) & 2901.35 \\
\hline Crude protein $(\%)$ & 20.03 \\
\hline Crude fat $(\%)$ & 5.04 \\
\hline Crude fiber $(\%)$ & 2.31 \\
\hline Methionine (\%) & 0.59 \\
\hline Lysine $(\%)$ & 1.37 \\
\hline Methionine + Cysine $(\%)$ & 0.96 \\
\hline $\mathrm{Ca}(\%)$ & 3.11 \\
\hline $\mathrm{P}$ available(\%) & 0.69 \\
\hline $\mathrm{Na}(\%)$ & 0.24 \\
\hline \multicolumn{2}{|c|}{$\begin{array}{l}\text { Note: }{ }^{1} \text { Premix composition Each } 10 \mathrm{~kg} \text { contains vitamin A: } 12.000 .000 \\
\text { IU, vitamin D3: } 2.000 .000 \mathrm{IU} \text {, vitamin E: } 8.000 \mathrm{IU} \text {, vitamin K: } 2.000 \\
\mathrm{mg} \text {, vitamin B1: } 2.000 \mathrm{mg} \text {, vitamin B2: } 500 \mathrm{mg} \text {, vitamin B6, vitamin } \\
\text { B12: } 12.000 \mathrm{~g} \text {, vitamin C: } 25.000 \mathrm{mg} \text {, Calcium-D-anthothenate: } 6.000 \\
\mathrm{mg} \text {, Niacin: } 40.000 \mathrm{mg} \text {, Choline chloride: } 10.000 \mathrm{mg} \text {, Lysine: } 30.000 \\
\mathrm{mg} \text {, Manganese: } 120.000 \mathrm{mg} \text {, Iron: } 20.000 \mathrm{mg} \text {, Iodine: } 200 \mathrm{mg} \text {, Zinc: } \\
100.000 \mathrm{mg} \text {, Cobalt: } 200 \mathrm{mg} \text {, Copper: } 4.000 \mathrm{mg} \text {, Zinc Bacitracin: } \\
21.000 \text { mg. 2 Formulated based on nutrient requirement } \\
\text { recommendations by Leeson and Summers (2005). }\end{array}$} \\
\hline
\end{tabular}

Table 2. Chemical quality characteristics of fermented whey cheese

\begin{tabular}{lc}
\hline Indices & Contents \\
\hline Alcohol (\%) & 3.18 \\
Acetic acid (\%) & 0.21 \\
Lactic acid (\%) & 0.29 \\
pH & 3.70 \\
Titratable Acidity & 0.579 \\
Antioxidant & 38.91 \\
Lipid (\%) & 0.20 \\
Protein (\%) & 0.27 \\
Lactic acid bacteria (log CFU / milliliter) & 10.27 \\
Total Plate Count (log CFU / milliliter) & 2.60 \\
Yeast (log CFU / milliliter) & 8.11 \\
\hline
\end{tabular}




\section{Experiment design and measurements}

Feed and water were given ad libitum. Drinking water in P1 treatment was added by $3 \%$ whey cheese fermented into the water, while P0 gave only water without fermented whey cheese. Feed intake was measured every week, while egg production and weight were recorded daily during treatment. The parameters observed in this study were the performance of laying yamsincluding feed consumption, egg production, egg mass weight, egg weight, feed conversion, and microbiology.

\section{Data analyses}

All data were expressed as mean \pm standard deviation and analyzed using T-tests. The analysis was considered significant at $\mathrm{p}<0.05$ using the Statistical Package for Social Sciences (SPSS version 21) for windows.

\section{RESULTS AND DISCUSSION}

\section{Production of laying hens}

Analysis of the productivity of laying hens aged 1726 weeks can be seen in table 3. The effect of adding fermented whey cheese into drinking water $(p<0.001)$ decreased feed consumption and feed conversion ratio (FCR) compared to the control treatment (P0) but increased egg production, egg weight, and egg mass weight. The decrease in feed consumption and feed conversion ratio (FCR) was around $0.9 \%$ and $11.8 \%$ (p < 0.001) compared to the control treatment while the increase in final body weight, egg production, egg weight, and egg mass weight were $4.13 \%, 6.41 \%, 12.59 \%$, and $19.27 \%$.

Table 3 Effect of fermented whey cheese added to the drinking water of the productivity of laying hens

\begin{tabular}{|c|c|c|c|c|}
\hline \multirow{2}{*}{ Variable } & \multicolumn{2}{|c|}{ Treatment } & \multirow{2}{*}{ SEM } & \multirow{2}{*}{ P- value } \\
\hline & P0 & P1 & & \\
\hline Feed intake (gram /hen/ day) & $105.90^{\mathrm{a}}$ & $104.91^{\mathrm{b}}$ & 0.15 & $<0.001$ \\
\hline $\begin{array}{l}\text { Initial Body Weight (gram / } \\
\text { hen) }\end{array}$ & 1455.00 & 1465.5 & 3.19 & 0.102 \\
\hline $\begin{array}{l}\text { Body weight gain (gram } \\
\text { /hen) }\end{array}$ & $1776.80^{\mathrm{b}}$ & $1850.20^{\mathrm{a}}$ & 10,98 & $<0.001$ \\
\hline Egg production (\%) & $75.21^{\mathrm{b}}$ & $80.03^{\mathrm{a}}$ & 0.69 & $<0.001$ \\
\hline Egg weight (gram ) & $59.48^{\mathrm{b}}$ & $66.97^{\mathrm{a}}$ & 0.88 & $<0.001$ \\
\hline $\begin{array}{l}\text { Egg mass weight (gram } \\
\text { /hen/day) }\end{array}$ & $44.93^{\mathrm{b}}$ & $53.59^{\mathrm{a}}$ & 1.04 & $<0.001$ \\
\hline FCR & $1.78^{\mathrm{a}}$ & $1.57^{\mathrm{b}}$ & 0.03 & $<0.001$ \\
\hline
\end{tabular}

\section{Feed intake}

Analysis of the productivity of laying hens aged 1826 weeks can be seen in table 3. Effect of adding fermented whey cheese into drinking water decreased $(\mathrm{p}<$ 0.01) feed consumption. Decreased feed consumption was due to the content of lactic acid bacteria and yeast that were in the fermentation of whey cheese which can split nutrients in the small intestine, so that absorption of nutrients in the body was food leaded to reduction in feed consumption (Mahfuz et al., 2017). Further, Taklimi et al. (2012) stated that giving probiotics such as lactic acid bacteria and yeast would reduce feed consumption. In contrast to the research of Toghyani et al. (2015), using molasses and fermented milk kefir grains did not affect the decrease in feed consumption.

\section{Body weight gain}

The administration of fermented whey cheese had a very significant effect on increasing the body weight of 26-week-old laying hens (P1) compared to conventional drinking water treatment $(\mathrm{P} 0)$. This increase in body weight was due to the content of lactic acid bacteria and yeasts which present in whey cheese fermented with kefir seeds that could inhibit pathogenic bacteria in the digestive tract, so the degradation of nutrients in the feed was easily appropriately absorbed. Kefir is a natural product that contains a complex mixture of lactic acid bacteria and yeasts, which acts as a probiotic (Fuller, 1989; Toghyani et al., 2015). Probiotics can improve intestinal health by inhibiting the growth of pathogens, resulting in better digestion and absorption of nutrients. According to Yaman et al., (2006), adding kefir into drinking water significantly increased the population of Lactobacilli spp. also, total aerobic bacteria populations and decreased the populations of Enterobacteriaceae so the absorption of nutrients would be better.

\section{Egg production}

Increased egg production at the age of 18-26 weeks was thought to be related with the presence of lactic acid bacteria and yeast in the small intestine and large intestine, by suppressing pathogenic bacteria and stimulating the growth of usefull bacteria which would increase the absorption capacity and digestibility of proteins, as well as increasing the egg production (Sathya and Muragian, 2015; Lokapirnasari et al., 2017). Protein is necessary for poultry body growth, healing damaged tissue, and also for the production and egg-forming elements. Using lactic acid bacteria and yeasts could produce an acidic atmosphere in the digestive tract, thereby suppressing the 
growth of pathogenic bacteria. A suitable condition of the digestive tract increases the metabolic process and absorption of necessary nutrients for the body, and also help increasing egg production, eggshell weight, eggshell thickness, and reducing cholesterol levels in egg yolks (Chaucheyras-Durand and Durand 2009; Delia et al., 2012; Lokapirnasari et al., 2017).

\section{Egg weight and egg mass weight}

The increase in egg weight and egg mass weight was highly significant $(\mathrm{p}<0.01)$ by the administration of fermented whey cheese (P1) compared to the control treatment (P0) (Table 3). Increased egg weight and egg mass weight was related to the content of lactic acid bacteria in the digestive tract which inhibit pathogenic bacteria that use protein in the small intestine. According to Huda et al. (2019), the utilization of lactic acid bacteria, which was applied to animal feed, could inhibit the growth of pathogenic microbes in the small intestine so that protein absorption improved and egg weight automatically increased. Furthermore, Pradikta et al. (2018) explained that the Absorption Rate of food substances in the digestive tract would work better with the help of lactic acid bacteria; and food substances contained in the feed, such as protein and amino acids, would be better absorbed in the chicken's body. This protein and amino acids would be used later by chickens to produce eggs, so if the absorption is not optimal, then production will also be not good. According to Istinganah et al. (2013), the essential factor to influence egg weight was protein and amino acid content, because about $50 \%$ of the dry matter contained in eggs is protein, therefore amino acids supplement was essential in the process of egg formation.

\section{Feed conversion ratio}

The addition of fermented whey cheese significantly decreased the FCR of laying hens aged 18 to 26 weeks (P1) compared to conventional drinking water treatment (P0) (Table 3). The decrease in FCR was caused by a decrease in feed consumption. According to Huda et al. (2019) who stated that the effective factor of FCR was the adequate nutritional content of the feed. The high FCR in the control treatment without whey fermentation was due to a high feed consumption, so that the absorption of nutrients for egg production was due to the enhanced activity of pathogenic, the digestibility, and the metabolic energy that caused the rate of movement of food in the digestive tract to be faster (Jadhav et al., 2015). The faster movement of feed affected the efficiency of ingesting food used to make eggs (Kabir, 2009; Jadhav et al., 2015;
Mousavi et al., 2018). Furthermore, Toghyani et al. (2015) stated that adding milk kefir and kefir molasses could reduce the FCR due to the increase of microbiota in fine milk, whichwas beneficial for absorption of feed nutrients and decreasing the consumption .

\section{laying hens \\ Gastrointestinal microflora and ammonia in}

Microbiological analysis of 26-week-old laying hens can be seen in table 4 . The effect of adding fermented whey cheese into drinking water decreased $(p<0.01)$ the number of Escherichia coli and increased lactic acid bacteria in the digestive tract of broiler chickens, especially in the ileum, caeca, and also in the stool. The number of Salmonella bacteria was significantly $(\mathrm{p}<0.05)$ decreased and very significantly $(\mathrm{p}<0.01)$ increased lactic acid bacteria in the feces during the fermentation of whey cheese. The decrease of ammonia in the stool was very significant $(\mathrm{p}<0.01)$ compared to the control. The decrease in the population of Escherichia coli in the intestine and salmonella in the stool was related to the increase in lactic acid bacteria that produced various organic acid components such as lactic acid and acetic acid and decreased the value of intestinal $\mathrm{pH}$ (Engberg et al., 2009).

Table 4. Effect of whey cheese fermentation into drinking water on gastrointestinal microflora, excreta, and ammonia laying hens at 26 weeks.

\begin{tabular}{llllll}
\hline \multirow{2}{*}{ Variable } & \multicolumn{3}{c}{ Treatment } & \multirow{2}{*}{ SEM P-value } \\
\cline { 2 - 5 } & P0 & P1 & & \\
\hline Escherichia coli & & & & \\
Ileum (log CFU / gram) & $5.67^{\mathrm{a}}$ & $5.18^{\mathrm{b}}$ & 0.08 & $<0.01$ \\
Caeca (log CFU / gram) & $7.17^{\mathrm{a}}$ & $6.40^{\mathrm{b}}$ & 0.10 & $<0.001$ \\
Lactic acid bacteria & & & & \\
Ileum (log CFU / gram) & $7.12^{\mathrm{b}}$ & $8.19^{\mathrm{a}}$ & 0.16 & $<0.001$ \\
Caeca (log CFU / gram) & $7.17^{\mathrm{b}}$ & $8.39^{\mathrm{a}}$ & 0.15 & $<0.001$
\end{tabular}

Excreta

$\begin{array}{lcccc}\text { Lactic acid bacteria (log CFU / gram) } & 5.57^{\mathrm{b}} & 7.29^{\mathrm{a}} & 0.23 & <0.001 \\ \text { Escherichia coli (log CFU / gram) } & 4.60 & 4.51 & 0.12 & 0.664 \\ \text { Salmonella (log CFU / gram) } & 4.33^{\mathrm{a}} & 3.79^{\mathrm{b}} & 0.13 & 0.028 \\ \mathrm{NH}_{3} \text { (ppm) } & 3.73^{\mathrm{a}} & 2.59^{\mathrm{b}} & 0.17 & <0.001\end{array}$

$\overline{\mathrm{a}, \mathrm{b}, \mathrm{c}, \mathrm{d}}=$ Means within a column with different superscripts differ significantly $(\mathrm{p}<0.05) . \mathrm{P0}=$ Control (without fermentied whey cheese), $\mathrm{P} 1=$ Fermenting whey cheese, SEM = Standard Error Mean, $\log =$ logarithm, CFU $=$ Colony Forming Unit, ppm = part per million

According to Canibe and Jensen (2003) and Kabir (2009) feed that contains a lot of lactic acid bacteria would produce high concentrations of lactic acid and acetic acid 
and lower the $\mathrm{pH}$ to made a hostile environment for growth of gram-negative bacteria that are sensitive to acids such as Campylobacter, Salmonella, and Escherichia coli. An increase in lactic acid bacteria in the feces would also affect the production of organic acids that could break the chain of reaction of urea formation. According to Mi et al. (2019) lactic acid bacteria could produce more effective acid to reduce ammonia in chicken feces, so the amount of $\mathrm{H}^{+}$ions would be high. $\mathrm{H}^{+}$ions in chicken feces could convert ammonia to ammonium $\left(\mathrm{NH}^{+}\right)$so the formation of ammonia emissions by gram-negative bacteria could be prevented (Kabir, 2009; Pezzuolo et al., 2019).. Lactic acid bacteria produce acidand are proteolytic, so they can reduce ammonia by breaking down the protein in uric acid. Lactic acid bacteria utilized uric acid as a nutrient and broke it down to the monomers. This resulted in decreasing ammonia production because of the availability of uric acid to be converted to ammonia is reduced. Lactic acid bacteria also produced bacteriocin (antibiotics), which suppressed the growth of pathogenic gram-negative bacteria which produced ammonia (Dhama et al., 2011; Park et al., 2016; Chen et al., 2017). This suppression of bacterial growth resulted in decrease of producing the urease enzyme from gram-negative bacteria which used to convert uric acid to ammonia (Mi et al., 2019; Pezzuolo et al., 2019). Mi et al. (2019) indicated that the $\mathrm{pH}$ of the stool is very important for the release of ammonia in the stool. A decrease in $\mathrm{pH}$ will change ammonia $\left(\mathrm{NH}_{3}\right)$ to ammonium $\left(\mathrm{NH}_{4}^{+}\right)$, which is more water-soluble, and making it less volatile than $\mathrm{NH}_{3}$.

\section{CONCLUSION}

Adding 3\% fermented whey cheese to drinking water can reduce feed consumption, FCR, Escherichia coli, salmonella, ammonia $\left(\mathrm{NH}_{3}\right)$, and increase egg production, egg weight, egg weight, final body weight, and lactic acid bacteria. The fermented whey cheese could be used as a nutraceutical feed additive in increasing the productivity of laying hens.

\section{DECLARATIONS}

\section{Consent to publish}

All authors gave their informed consent before their inclusion in the study.

\section{Competing interests}

The authors declare that there is no competing interest in this research.

\section{Authors' contribution}

The authors contributed to arrange the experimental research, determine the method of analysis, preparation of materials method, study, and data analyzed. The authors confirmed the final revised article for publishing in this journal.

\section{Acknowledgements}

Politeknik Negeri Banyuwangi funded this research through the RIP Research program. We are very thankful to Politeknik Negeri Banyuwangi for supporting this program. We are very grateful to Politeknik Negeri Banyuwangi for supporting and financing through the RIP Research program with Research Contract No. 338.32 / PL36 / PT.01.09 / 2019 and Director of Politeknik Negeri Banyuwangi.

\section{REFERENCES}

Ariyanti D and Hadiyanto H (2013). Pembuatan Bioetanol Dari Limbah Keju (Whey) Melalui Proses Fermentasi Fed-batch Dengan Kluyveromyces Marxianus. Journal Teknologi Kimia dan Industri, 2(2): 155-162. Available at: https://ejournal3.undip.ac.id/index.php/jtki/article/view/2839.

Bhattacharyya A and Roy D (2015). Nutraceuticals in livestock and poultry: New India Publishing Agency.

Canibe N and Jensen BB (2003). Fermented and nonfermented liquid feed to growing pigs: effect on aspects of gastrointestinal ecology and growth performance. Journal of Animal Science, 81(8): 20192031. DOI: https://doi.org/10.2527/2003.8182019x.

Charalampopoulos D and Rastall RA (2009). Prebiotics and probiotics science and technology: Springer.

Chaucheyras-Durand F and Durand H (2009). Probiotics in animal nutrition and health. Beneficial microbes, 1(1):3-9. DOI: https://doi.org/10.3920/BM2008.1002.

Chen CY, Chen SW and Wang HT (2017). Effect of supplementation of yeast with bacteriocin and Lactobacillus culture on growth performance, cecal fermentation, microbiota composition, and blood characteristics in broiler chickens. Asian-Australasian journal of animal sciences, 30(2): 211-220. DOI: https://doi.org/10.5713/ajas.16.0203.

Delia E, Tafaj M and Männerin K (2012). Efficiency of probiotics in farm animals. Probiotic in animals: Di dalam: E C Rigobelo, editor Croatia, BoD-Books on Demand. Available at: https://www.intechopen.com/books/probiotic-in-animals/efficiencyof-probiotics-in-farm-animals: 247-272.

Dhama K, Verma V, Sawant PM, Tiwari R, Vaid R and Chauhan RS (2011). Applications of Probiotics in Poultry: Enhancing Immunity and Beneficial Effects on Production Performances and Health - A Review. Journal of IImmunology and Immunopathology, 13:1-19. Available http://www.indianjournals.com/ijor.aspx?target=ijor:jii\&volume=1 $3 \&$ issue $=1 \&$ article $=001$.

Engberg RM, Hammersh J, Johansen N, Abousekken MS, Steenfeldt S and Jensen BB (2009). Fermented feed for laying hens: effects on egg production, egg quality, plumage condition and composition 
and activity of the intestinal microflora. British poultry science, 50(2): 228-239. DOI: https://doi.org/10.1080/00071660902736722.

FASS (2010). Guide for the Care and Use of Agricultural Animals in Research and Teaching: FASS Champaign, IL. DOI or Available at:

Fuller R (1989). Probiotics in man and animals. The Journal of applied bacteriology, 66(5): 365-378. DOI: https://doi.org/10.1111/j.13652672.1989.tb05105.x.

Huda K, Lokapirnasari W, Soeharsono S, Hidanah S, Harijani N and Kurnijasanti R (2019). Pengaruh Pemberian Probiotik Lactobacillus acidophilus dan Bifidobacterium terhadap Produksi Ayam Petelur yang Diinfeksi Escherichia coli. Jurnal Sain Peternakan Indonesia, 14(2): 154-160. DOI: https://doi.org/10.31186/jspi.id.14.2.154-160.

Istinganah L, Mugiyono S and Iriyanti N (2013). Penggunaan Berbagai Jenis Probiotik Dalam Ransum Terhadap Produksi Dan Bobot Telur Ayam Arab. Jurnal Ilmiah Peternakan, 1(1):338-346. Available at: https://www.e-jurnal.com/2016/10/penggunaan-berbagai-jenisprobiotik.html.

Jadhav K, Sharma K, Katoch S, Sharma V and Mane B (2015). Probiotics in broiler poultry feeds: A review. Journal of Animal Nutrition and Physiology, 1: 04-16. Available at: https://pdfs.semanticscholar.org/7e66/c9a51d93f0c7ed838f4d38d62 79e446f4710.pdf.

Jin L, Ho Y, Abdullah N and Jalaludin S (2000). Digestive and bacterial enzyme activities in broilers fed diets supplemented with Lactobacillus cultures. Poultry science, 79(6): 886-891. DOI: https://doi.org/10.1093/ps/79.6.886.

Kabir S (2009). The role of probiotics in the poultry industry. International Journal of Molecular Sciences, 10(8): 3531-3546. DOI: https://doi.org/10.3390/ijms10083531.

Kabir S, Rahman M, Rahman M, Hosain M, Akand M and Das S (2005). Viability of probiotics in balancing intestinal flora and effecting histological changes of crop and caecal tissues of broilers. Biotechnology, $\quad 4(4)$ : $\quad 325-330 . \quad$ DOI: https://doi.org/10.3923/biotech.2005.325.330.

Leeson S and Summers JD (2005). Commercial Poultry Nutrition, third edition: Nottingham University Press.

Lokapirnasari WP, Dewi AR, Fathinah A, Hidanah S and Harijani N (2017). Effect of probiotic supplementation on organic feed to alternative antibiotic growth promoter on production performance and economics analysis of quail. Veterinary world, 10(12):1508. DOI: https://doi.org/10.14202/vetworld.2017.1508-1514.

Mahfuz S, Nahar M, Mo C, Ganfu Z, Zhongjun L and Hui S (2017). Inclusion of probiotic on chicken performance and immunity: A Review. International Journal of Poultry Science, 16:328-335. DOI: https://doi.org/10.3923/ijps.2017.328.335.

Mellor S (2000). Nutraceuticals-alternatives to antibiotics. World Poultry, 16(2):30-33. Available at: https://www.cabdirect.org/cabdirect/abstract/20001413878.

Mi J, Chen X and Liao X (2019). Screening of single or combined administration of 9 probiotics to reduce ammonia emissions from laying hens. Poultry science, 98(9): 3977-3988. DOI: https://doi.org/10.3382/ps/pez138.

Mousavi A, Ali SM, Mahmoodzadeh Hosseini H and Mirhosseini SA (2018). A Review of Dietary Probiotics in Poultry. Journal of
Applied Biotechnology Reports, 5(2):48-54. DOI: https://doi.org/10.1079/WPS19850008.

Nursiwi A, Utami R, Andriani M and Sari AP (2015). Fermentasi Whey Limbah Keju Untuk Produksi Kefiran Oleh Kefir Grains. Jurnal Teknologi Hasil Pertanian, 8(1):37-45. DOI: https://doi.org/10.20961/jthp.v0i0.12794.

Park J, Jeong J, Lee S and Kim I (2016). Effect of dietary supplementation with a probiotic (Enterococcus faecium) on production performance, excreta microflora, ammonia emission, and nutrient utilization in ISA brown laying hens. Poultry science, 95(12): 2829-2835. DOI: https://doi.org/10.3382/ps/pew241.

Pezzuolo A, Sartori C, Vigato E and Guercini S (2019). Effect of litter treatment with probiotic bacteria on ammonia reduction in commercial broiler farm. Jelgava, Latvia University of Life Sciences and Technologies Faculty of Engineering.

Pradikta RW, Sjofjan O and Djunaidi IH (2018). Evaluasi penambahan probiotik (Lactobacillus sp) cair dan padat dalam pakan terhadap penampilan produksi ayam petelur. Jurnal Ilmu-Ilmu Peternakan, 28(3): 203-212. DOI: https://doi.org/10.21776/ub.jiip.2018.028.03.03.

Prasetyo B, Kustiawan E (2012). Pemanfaatan Whey Fermentasi Sebagai "Funtional Feed" Dalam Meningkatkan Performans Ayam Broiler. Jurnal Ilmiah Inovasi, 12(1): 84-88. DOI: https://doi.org/10.25047/jii.v12i1.331.

Sathya C and Muragian P (2015). Effect of dietary supplementation of probiotic and Curculigo orchioides rhizome powder on egg quality parameters and biochemical composition of Japanese quail (Coturnix coturnix japonica). International Journal Of Advances in Pharmacy Biology and Chemistry, 4(1):162-170. Available at: http://www.ijapbc.com/files/23-4128.pdf.

Sugiharto S (2016). Role of nutraceuticals in gut health and growth performance of poultry. Journal of the Saudi Society of Agricultural Sciences, 15(2):99-111. DOI: https://doi.org/10.1016/j.jssas.2014.06.001.

Taklimi SMSM, Lotfollahian H, Shahne AZ, Mirzaei F and Alinejad A (2012). Study on efficacy of probiotic in broiler chickens diet. Agricultural Sciences 3(01):5. DOI: https://doi.org/10.4236/as.2012.31002.

Toghyani M, kazem Mosavi S, Modaresi M and Landy N (2015). Evaluation of kefir as a potential probiotic on growth performance, serum biochemistry and immune responses in broiler chicks. Animal Nutrition, 1(4): 305-309. DOI: https://doi.org/10.1016/j.aninu.2015.11.010.

Watson RR, Collier RJ and Preedy VR (2017). Dairy in Human Health and Disease across the Lifespan: Academic Press.

Yaman H, Ulukanli Z, Elmali M and Unal Y (2006). The effect of a fermented probiotic, the kefir, on intestinal flora of poultry domesticated geese (Anser anser). Revue de médecine vétérinaire, 157(7): 379-386. Available at: https://www.revmedvet.com/2006/RMV157_379_386.pdf.

Youssef AW, Hassan H, Ali H and Mohamed M (2013). Effect of probiotics, prebiotics and organic acids on layer performance and egg quality. Asian Journal Poultry Science, 7(2):65-74. DOI: https://doi.org/10.3923/ajpsaj.2013.65.74. 